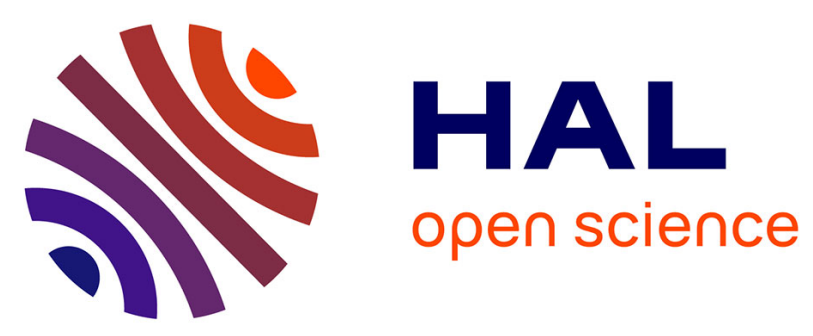

\title{
Prospects for Using Environmental Levers in Greenhouses to Stimulate Plant Defences and the Quality of Fruits and Vegetables.
}

\author{
Laurent Urban, Jawad Aarrouf, Philippe C. Nicot
}

\section{To cite this version:}

Laurent Urban, Jawad Aarrouf, Philippe C. Nicot. Prospects for Using Environmental Levers in Greenhouses to Stimulate Plant Defences and the Quality of Fruits and Vegetables.. Acta Horticulturae, 2014, 1041, pp.247-252. 10.17660/ActaHortic.2014.1041.29 . hal-01332501

\author{
HAL Id: hal-01332501 \\ https://hal.science/hal-01332501
}

Submitted on 27 May 2020

HAL is a multi-disciplinary open access archive for the deposit and dissemination of scientific research documents, whether they are published or not. The documents may come from teaching and research institutions in France or abroad, or from public or private research centers.
L'archive ouverte pluridisciplinaire HAL, est destinée au dépôt et à la diffusion de documents scientifiques de niveau recherche, publiés ou non, émanant des établissements d'enseignement et de recherche français ou étrangers, des laboratoires publics ou privés.

\section{다(1)(2)}

Distributed under a Creative Commons Attribution - ShareAlikel 4.0 International 


\title{
PROSPECTS FOR USING ENVIRONMENTAL LEVERS IN GREENHOUSES TO STIMULATE PLANT DEFENCES AND THE QUALITY OF FRUITS AND VEGETABLES
}

\author{
Authors \\ L. Urban, A. Jawad, P.C. Nicot
}

\section{Abstract}

The environment of greenhouses is commonly modified to reduce the pressure of pests and diseases, but it can also be exploited to stimulate natural defences of plants. In addition to genetic influences, several agronomic factors can be used as levers to increase the concentrations of secondary metabolites involved in the defence of fruit and vegetable crops. Many secondary metabolites involved in plant defences are also phytonutrients, i.e., compounds that have beneficial effects on human health, including protection against cardiovascular diseases, cancers, and metabolic or neurodegenerative diseases. Nitrogen deprivation, photooxidative stress and exposure to specific wavelengths such as those supplied by UV radiations are well known for stimulating the production of secondary metabolites in a large range of plants. We propose here a review of factors meeting the specifications of organic farming, which are both effective and applicable in greenhouse conditions. Among all these factors, mild stress and innovative covering materials emerge as especially promising.

\section{Citation}

Urban, L., Jawad, A. and Nicot, P.C. 2014. PROSPECTS FOR USING ENVIRONMENTAL LEVERS IN GREENHOUSES TO STIMULATE PLANT DEFENCES AND THE QUALITY OF FRUITS AND VEGETABLES. Acta Hort. (ISHS) 1041:247-252

http://www.actahort.org/books/1041/1041_29.htm

\section{Keywords}

light, organic farming, secondary metabolism, stress

\section{Language \\ English}

\section{Full text}

http://www.actahort.org/members/showpdf?booknrarnr=1041_29

\section{Acta Horticulturae 1041}

II International Symposium on Organic Greenhouse Horticulture

\section{Article number}

1041_29

Pages

247-252

\section{Groups}

- Commission Organic Horticulture

- Commission Protected Cultivation

- Workgroup Organic Greenhouse Horticulture 